\title{
PENYULUHAN HUKUM TENTANG PERANAN ALAT-ALAT BUKTI DALAM PENYELESAIAN PERKARA PERDATA
}

\section{Legal Education on The Role of Evidence Tools in Civil Procedure Settlement}

\author{
Mualifah \\ Program Studi Ilmu Hukum Universitas Mataram \\ Jalan Majapahit No.62 Kota Mataram \\ Alamat korespondensi : mualifah@unram.ac.id
}

(Tanggal Submission: 4 November 2020, Tanggal Accepted: 28 Desember 2020)

\begin{abstract}
ABSTRAK
Suatu pembuktian menurut hukum pada dasarnya merupakan proses untuk menentukan substansi atau hakekat adanya fakta-fakta yang diperoleh melalui ukuran yang layak dengan fikiran yang logis terhadap fakta-fakta pada masa lalu yang tidak terang menjadi fakta-fakta yang terang dalam hubungannya dengan perkara yang diperiksa. Membuktikan sesuatu adalah suatu pekerjaan yang amat sukar sehingga sering kali aparat penegak hukum menjumpai kesulitan akibatnya banyak perkara perdata yang tidak dapat dibuktikan secara sempurna. Seperti yang telah dikemukakan, maka yang harus dibuktikan adalah peristiwa dan bukan hukumnya. Tujuan kegiatan pengabdian kepada masyarakat ini adalah untuk menyebar luaskan informasi mengenai betapa pentingnya pembuktian dalam perkara perdata terutama dalam penyelesaian perkara perdata yang harus menyertakan alatalat bukti dalam pembuktian sebagai sarana atau alat untuk menyelesaikan suatu perkara yang merupakan kunci utama dalam menentukan dan menyelesaikan perkara perdata. Disamping itu juga penyuluah ini diharapkan dapat meningkatkan pengetahuan dan kesadaran hukum pada masyarakat. Hasil dan kesimpulan kegiatan pengabdian kepada masyarakat ini adalah masyarakat Lingkungan Gatep Permai kurang mendapat informasi mengenai peran alat bukti dalam penyelesaian suatu perkara perdata, hal ini dibuktikan dengan besarnya antusias masyarakat pada kegiatan diskusi tanya jawab. Sehingga harapkan diadakannya kembali penyuluhan hukum secara berkesinambungan dengan materi hukum yang lain atau yang aktual.
\end{abstract}

Kata Kunci : Alat Bukti, Perkara Perdata, Pembuktian

\section{PENDAHULUAN}

Dari berbagai tahap pemeriksaan perkara perdata, pembuktian merupakan tahap yang penting dan menentukan. Dikatakan penting karena pada tahap pembuktian inilah nanti seseorang dapat diprediksi menang atau kalah, dikatakan menentukan karna alat-alat bukti itulah nantinya yang menjadi dasar bagi aparat penegak hukum khususnya hakim dalam memproses perkara para pihak bahkan menjadi dasar bagi hakim untuk menjatuhkan putusan. 
Suatu pembuktian menurut hukum pada dasarnya merupakan proses untuk menentukan substansi atau hakekat adanya fakta-fakta yang diperoleh melalui ukuran yang layak dengan fikiran yang logis terhadap faktafakta pada masa lalu yang tidak terang menjadi fakta-fakta yang terang dalam hubungannya dengan perkara yang diperiksa.

Oleh karena itu dalam membuktikan suatu perkara perdata, pemeriksaan di sidang pengadilan melakukan penelitian dan koreksi dalam menghadapi masalah dari berbagai fakta untuk mendapatkan suatu konklusi dengan metode ilmu logika. Seperti yang telah dikemukakan, maka yang harus dibuktikan adalah peristiwa dan bukan hukumnya. Peristiwa-peristiwa yang dikemukakan oleh penggugat dan tergugat belum tentu semuanya penting bagi hakim guna dasar pertimbangan dari pada putusannya. Peristiwa-peristiwa itu harus disaring oleh hakim, harus dipisahkan mana yang penting bagi hukum dan mana yang tidak. Peristiwa yang relefan itu lah yang harus ditetapkan dan oleh karena itu harus dibuktikan. Misalnya yang harus dibuktikan ialah adanya perjanjian hutang-pihutang antara penggugat dan tergugat. Tidaklah relefan bagi hukum apakah pengggugat pada waktu mengadakan perjanjian tersebut telah memakai baju batik dan tergugat sedang merokok. Yang relefan bagi hakim adalah apakah benar-benar pada waktu dan tempat tertentu telah terpenuhi syarat-syarat sahnya perjanjian sehingga terjadilah perjanjian hutang-piutan tertentu anatara kedua belah pihak.

Pembuktian adalah kepastian yang diberikan kepada hakim dipersidangan tentang adanya peristiwa-peristiwa tertentu. Alat-alat bukti yang diberikan oleh para pihak harus berkaitan dengan peristiwa atau kejadian yang sedang disengketakan.Alat-alat bukti dalam perkara perdata sebagaimana yang ditentukan dalam HIR/ RBg ada 5 yaitu:
1. pengakuan

2. Alat Alat bukti tertulis

3. Alat bukti saksi

4. Alat bukti persangkaan

5. Alat bukti bukti sumpah

Menurut Sudikno Mertokusumo dalam bukunya yang berjudul "Hukum Acara Perdata Indonesia" mengatakan bahwa membuktikan mengandung beberapa pengertian yaitu arti logis, konvensional dan yuridis. Membuktikan dalam arti logis adalah memberikan kepastian yang bersifat mutlak, karena berlaku bagi setiap orang dan tidak memungkinkan adanya bukti lawan. Untuk membuktikan dalam arti konvensional, di sini pun berarti juga memberi kepastian, hanya saja bukan kepastian mutlak, melainkan kepastian nisbi atau relatif sifatnya dan membuktikan dalam arti yuridis tidak lain berarti memberi dasar yang cukup kepada hakim yang memeriksa perkara yang bersangkutan guna memberi kepastian tentang kebenaran peristiwa yang diajukan.

Kesaksian merupakan alat bukti yang wajar, karena keterangan yang diberikan kepada hakim dipersidangan itu berasal dari pihak ketiga yang melihat atau mengetahui sendiri peristiwa yang bersangkutan. Pihak ketiga pada umumnya melihat peristiwa yang bersangkutan lebih obyektif dari pada pihak yang berkepentingan sendiri yaitu para pihak yang berperkara pada umumnya akan mencari benarnya sendiri. Betapa pentingnya arti kesaksian sebagai alat bukti tampak dalam kenyataan bahwa banyak peristiwa-peristiwa hukum yang tidak dicatat atau tidak ada alat bukti tertulisnya. Sehingga oleh karena itu kesaksian merupakan satu-satunya alat bukti yang tersedia.

Harus diakui bahwa tidak dapat dihindarkan kemungkinan adanya saksi palsu yang sengaja diajukan oleh pihak yang bersangkutan untuk memberikan keterangan yang tidak benar kepada hakim dipersidangan. 
Disamping itu harus disadari pula bahwa keterangan seorang saksi yang beritikat baik sekalipun untuk memberik keterangan yang benar dan tidak lain dari pada yang benar, masih kurang dapat dipercaya. Apabila suatu peristiwa itu telah lama terjadi, maka tidak jarang saksi tidak mengingat secara pasti beberapa kejadian. Sehingga untuk memberi kesaksian suatu peristiwa yang telah lama terjadi menjadi tidak mudah.

Kesaksian seorang saksi dapat dipercaya atau tidak tergantung pada banyak hal, sehingga menurut Pasal 172 HIR (Pasal 309 Rbg, 1908 BV) seorang hakim harus memperhatikan kesesuaian atau kecocokan antara keterangan para saksi, kesesuaian kesaksian dengan apa yang diketahui dari segi lain tentang perkara yang disengketakan pertimbangan yang mungkin ada pada saksi untuk menuturkan kesaksiannya cara hidup, adat istiadat serta martabat para saksi dan segala sesuatu yang sekiranya mempengaruhi tentang dapat tidaknya dipercaya seorang saksi. Untuk berpegangan ketat pada ketentuan tersebut diatas sangatlah sukar bagi hakim, karna itu berarti bahwa setiap saksi harus dinilai sesuai dengan cara hidup, adat istiadat serta martabatnya, yang sekiranya tidak semudah yang dibayangkan. Oleh karena itu dalam hal ini diserahkan pada pertimbangan hakim.

\section{METODE KEGIATAN}

Hal pertama yan dilakukan dalam kegiatan penyuluhan ini adalah pengurusan surat izin dari Kadus Lingkungan Gatep Permai. Kemudian mengundang masyarakat, yang dimana peserta-peserta penyuluhan ini ditentukan oleh Kadus Lingkungan Gatep Permai. Pada kegiatan penyuluhan ini dilaksanankan dengan cara ceramah dan diskusi. Adapun untuk indikator evaluasi pelaksanaan penyuluhan ini dilihat berdasarkan tingkat antusias peserta dalam mengajukan pertanyaan terkait materi yang diberikan.

\section{HASIL DAN PEMBAHASAN}

Sebagai langkah awal dalam kegiatan pengabdian, dilakukan peyuluhan hukum dengan cara ceramah dan tanya jawab. Penyuluhan ini dilakukan untuk memberi informasi kepada masyarakat tentang peranan alat-alat bukti dalam penyelesaian perkara perdata, sehingga dapat menambah wasawan masyarakat tentang pentingnya alat-alat bukti dalam penyelesaian perkara perdata. Materi yang diberikan pada kegiatan ini adalah pengertian alat bukti, macam macam alat bukti serta fungsi alat bukti tersebut dalam pembuktian suatu perkara perdata. Peserta penyuluhan sebanyak 30 orang yang merupakan warga dari Lingkungan Gatep Permai, yang diharapkan dapat memberikan informasi tentang peranan alat-alat bukti dalam penyelesaian perkara perdata kepada warga lainnya. Sehingga informasi tersebut dapat diketahui oleh seluruh warga Lingkungan Gatep Permai. Hal ini terlihat dari animo dan keserius peserta penyuluhan dalam mendengarkan materi dan banyak memberikan pertanyaan terkait materi yang disampaikan

Untuk menganalisa hasil dari kegiatan penyuluhan ini, apakah kegiatan yang telah dilakukan berhasil atau tidak, tentunya membutuhkan waktu yang lama. Jika setelah kegiatan ini apa yang dilakukan masyarakat Lingkungan gatep permai dan terkait dengan masalah-masalah sebagaimana yang telah disampaikan, dan jika masyarakat dalam hal ini memperhatikan serta melaksanakan dan memahami tentang peranan alat-alat bukti dalam penyelesaian perkara perdata. Evaluasi terhadap kegiatan ini dilakukan setelah kegiatan Ceramah dan Diskusi, yaitu memberikan kesempatan kepada para peserta untuk mengajukan pertanyaan kemudian tim 
menjawab dan setelah itu mengajukan pertanyaan balik kepada peserta suluh untuk mengetahui tanggapan para peserta mengenai tingkat pengetahuannya terhadap substansi atau materi penyuluhan.

\section{KESIMPULAN DAN SARAN}

Dari apa yang diuraikan pada bagian sebelumnya maka dapat ditarik kesimpulan bahwa masyarakat Lingkungan Gatep Permai kurang mendapat informasi mengenai peran alat bukti dalam penyelesaian suatu perkara perdata, hal ini dibuktikan dengan besarnya antusias masyarakat pada kegiatan diskusi tanya jawab. Sehingga harapkan diadakannya kembali penyuluhan hukum secara berkesinambungan dengan materi hukum yang lain atau yang aktual.

\section{DAFTAR PUSTAKA}

Mertokusumo, S.,2009. Hukum Acara Perdata Indonesia, Ed.7. Liberty:Yogyakarta. 